\title{
Knowledge on Pre-Hospital Emergency Management of Tooth Avulsion among Croatian Kindergarten Teachers
}

\author{
Zvonimir Užarević1, Zrinka Ivaniševićé, Tena Velki, Vesnica Mlinarević1, Vedrana Nikolašević1, \\ Nikola Matijević́2, Marko Matijević ${ }^{2}$
}

${ }^{1}$ Faculty of Education, University of Osijek, Osijek, Croatia

${ }^{2}$ Faculty of Dental Medicine and Health, University of Osijek, Osijek, Croatia

\begin{abstract}
A B S T R A C T
The aim of this study was to evaluate knowledge on pre-hospital emergency management of tooth avulsion among Croatian kindergarten teachers. A cross-sectional study was conducted among 33 educators in kindergarten (average

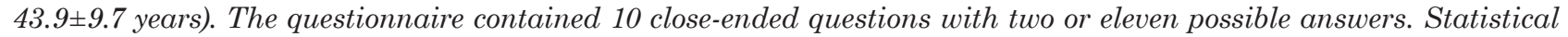
significance was determined using chi-square test. Majority of participants had no experience with tooth injury among children in kindergarten. Questions about the familiarity with the terms of a knocked-out tooth and tooth replantation and whether the knocked-out tooth should be replanted were confirmatively answered by $90.9 \%, 57.6 \%$ and $63.6 \%$ of participants, respectively. Only $9.1 \%$ of participants provided the correct answer that replantation should be done within 30 minutes. $78.8 \%$ of participants would choose correct medium for cleaning if avulsed tooth got dirty. Tooth would be transported in appropriate medium by $48.5 \%$ of participants. Correct answers on both the transport medium and the cleaning of knocked-out tooth were provided by $45.5 \%$ participants. $57.6 \%$ participants would seek help for replantation by visiting the nearest dentist. None of the participants had ever received any kind of information on management of a knocked-out tooth. The kindergarten teachers have a lack of knowledge for immediate response to tooth avulsion. Every kindergarten teacher should be well informed what should be done if some type of dental injury happens. The official communication between dental professionals and kindergarten teachers should be improved at local and regional level.
\end{abstract}

Keywords: tooth avulsion, dental trauma, kindergarten teachers

\section{Introduction}

The youngest population is at high risk of different injuries of primary and permanent dentition. Regarding age, it is found that children aged less than five and children aged six to ten have dental injuries in $24.9 \%$ and in $23.6 \%$ cases among patients of all ages, respectively'. The avulsion among dental injuries of primary teeth occurs more often than among dental injuries of permanent teeth ${ }^{2-3}$. Following instructions of the International Association of Dental Traumatology (IADT), the avulsed primary tooth should not be replanted, while permanent should ${ }^{4}$.

Appropriate immediate emergency response is very important for successful outcome of permanent tooth replantation. Low levels of awareness of proper response to tooth avulsion among different non-professional participants are frequently reported ${ }^{5-11}$. It is found that the kindergarten was the place of tooth avulsion in $3 \%$ cases for children aged one to three years and in $6.5 \%$ cases for children aged four to six years ${ }^{3}$.

Every employee that holds one of childcare professional positions, including the kindergarten teacher that guard over children with primary teeth, should be well informed to distinguish primary and permanent tooth after the tooth avulsion and to know the appropriate response to either the primary or the permanent tooth avulsion.

The aim of the study was to determine the knowledge of Croatian kindergarten teachers about the emergency management response to the permanent tooth avulsion.

\section{Participants and Methods}

\section{Participants}

A cross-sectional study was conducted among Croatian teachers employed in kindergartens. Participants (N=33) 
were females with average age of $43.9 \pm 9.7$ (range from 25 to 58) and $19.4 \pm 9.9$ years of working experience (range from 2 to 36). Participants were asked to fill out a selfadministered questionnaire. The objectives of the study were explained and the information of the study purpose was provided at the beginning of the questionnaire. Every participant could withdraw from the study at any time. The voluntary nature of the study was emphasized and confidentiality was assured.

\section{Questionnaire procedures}

The questionnaire was adopted ${ }^{9-11}$ and with minor changes translated into the respondents' native language, Croatian. Participants answered ten close-ended questions with 2 to 11 possible answers. The yes/no questions assessed the general experience of participants about dental injuries. The knowledge based part of the questionnaire included four questions with multiple correct answers. Every participant chose only one correct answer.

\section{Data collection and statistical analysis}

The answers were counted and a percentage for each question was calculated. Chi-square test was used to determine whether there is a statistically significant difference between the expected and the observed frequencies of incorrect and correct responses for each of knowledge based questions. Answers "I do not know" were not included. Statistical analysis was performed using the Statistical Package for the Social Sciences software (version 17, SPSS Inc., Chicago, IL, USA). The level of significance was set to $\mathrm{P}<0.05$.

\section{Results}

The response rate was $100 \%$ since all participants submitted the questionnaire. A total of $69.7 \%$ participants were over 40 years old with more than 15 years of working experience. Prior in life participants did not receive any kind of information regarding the management of a

TABLE 1

KINDERGARTEN TEACHER'S RESPONSES TO THE APPLIED QUESTIONNAIRE

\begin{tabular}{|c|c|c|}
\hline & Questions & $\mathrm{N}(\%)$ \\
\hline Q1 & $\begin{array}{l}\text { Do you have experience with tooth injury } \\
\text { among children in kindergarten? }\end{array}$ & \\
\hline $\mathrm{a}$ & Yes & $9(27.3)$ \\
\hline $\mathrm{b}$ & No & $24(72.7)$ \\
\hline Q2 & Do you know what knocked-out tooth is? & \\
\hline $\mathrm{a}$ & Yes & $30(90.9)$ \\
\hline $\mathrm{b}$ & No & $3(9.1)$ \\
\hline Q3 & Do you know what tooth replantation is? & \\
\hline $\mathrm{a}$ & Yes & $19(57.6)$ \\
\hline $\mathrm{b}$ & No & $14(42.4)$ \\
\hline Q4 & $\begin{array}{l}\text { If the tooth is knocked-out and falls on the } \\
\text { ground, do you know what should be done? }\end{array}$ & \\
\hline a & Yes & $19(57.6)$ \\
\hline $\mathrm{b}$ & No & $14(42.4)$ \\
\hline Q5 & $\begin{array}{l}\text { Should the knocked-out tooth be placed back } \\
\text { into the socket? }\end{array}$ & \\
\hline a & Yes & $21(63.6)$ \\
\hline $\mathrm{b}$ & No & $12(36.4)$ \\
\hline Q6 & $\begin{array}{l}\text { How immediately the tooth replantation } \\
\text { should be performed after the tooth comes } \\
\text { out of the socket? }\end{array}$ & \\
\hline a & 5 minutes * & $0(0)$ \\
\hline $\mathrm{b}$ & 30 minutes * & $3(9.1)$ \\
\hline $\mathrm{c}$ & 1 hour & $5(15.1)$ \\
\hline d & 6 hour & $3(9.1)$ \\
\hline e & 24 hour & $6(18.2)$ \\
\hline $\mathrm{f}$ & 72 hour & $0(0)$ \\
\hline $\mathrm{g}$ & I do not know & $16(48.5)$ \\
\hline Q7 & $\begin{array}{l}\text { If the tooth falls on the ground and gets } \\
\text { dirty, what should you do? }\end{array}$ & \\
\hline $\mathrm{a}$ & Brush crown and root & $0(0)$ \\
\hline
\end{tabular}

\begin{tabular}{|c|c|c|}
\hline & Questions & $\mathrm{N}(\%)$ \\
\hline $\mathrm{b}$ & Wash with tap water * & $6(18.2)$ \\
\hline $\mathrm{c}$ & Wash with milk * & $5(15.1)$ \\
\hline $\mathrm{d}$ & Wash with saline * & $15(45.4)$ \\
\hline e & Do not wash & $4(12.1)$ \\
\hline $\mathrm{f}$ & I do not know & $3(9.2)$ \\
\hline Q8 & First place to seek for replantation treatment? & \\
\hline a & Emergency hospital & $10(30.3)$ \\
\hline $\mathrm{b}$ & General hospital * & $0(0)$ \\
\hline $\mathrm{c}$ & Dentist nearby * & $19(57.6)$ \\
\hline d & Medical doctor & $0(0)$ \\
\hline $\mathrm{e}$ & Medical College & $0(0)$ \\
\hline $\mathrm{f}$ & Dental College & $3(9.1)$ \\
\hline $\mathrm{g}$ & Others & $1(3.0)$ \\
\hline Q9 & Transport media? & \\
\hline a & Tissue paper & $7(21.2)$ \\
\hline $\mathrm{b}$ & Toilet paper & $0(0)$ \\
\hline $\mathrm{c}$ & Cotton rolls & $2(6.1)$ \\
\hline$d$ & Pocket & $0(0)$ \\
\hline $\mathrm{e}$ & Poly bags & $2(6.1)$ \\
\hline $\mathrm{f}$ & Tap water & $2(6.1)$ \\
\hline $\mathrm{g}$ & Saline water * & $11(33.3)$ \\
\hline $\mathrm{h}$ & Milk * & $5(15.1)$ \\
\hline $\mathrm{i}$ & Saliva * & $0(0)$ \\
\hline $\mathrm{j}$ & Others & $0(0)$ \\
\hline $\mathrm{k}$ & I do not know & $4(12.1)$ \\
\hline Q10 & $\begin{array}{l}\text { Have you ever received any kind of } \\
\text { information on management of knocked- } \\
\text { out tooth? }\end{array}$ & \\
\hline a & Yes & $0(0)$ \\
\hline $\mathrm{b}$ & No & $33(100)$ \\
\hline
\end{tabular}

* correct answer 
knocked-out tooth (Table 1). The majority of participants had no experience with tooth injury among kindergarten children. Questions about the familiarity with the terms of a knocked-out tooth and tooth replantation and whether the knocked-out tooth should be replanted were confirmatively answered by $90.9 \%, 57.6 \%$ and $63.6 \%$ of participants, respectively. $57.6 \%$ of participants confirmed they knew what should be done if avulsed tooth fell on the ground (Table 1).

$78.8 \%$ of participants would choose a correct medium for cleaning if avulsed tooth got dirty. The majority of $57.6 \%$ participants would seek help for replantation treatment by visiting the nearest dentist. The tooth would be transported in an appropriate medium by $48.5 \%$ of participants. A statistically significant difference between expected and observed frequencies of incorrect and correct answers was found for three knowledge based questions, while no statistical significance was found for time of replantation (Table 2).

The correct answers about both the cleaning and the transport medium were provided by $45.5 \%$ of participants (Table 3). Most participants (48.5\%) did not know within what time replantation should be performed. Only $9.1 \%$ of

TABLE 2

DISTRIBUTION OF INCORRECT AND CORRECT RESPONSE FREQUENCY ON KNOWLEDGE BASED QUESTIONS

\begin{tabular}{ccccc}
\hline Questions & $\begin{array}{c}\text { Incorrect } \\
\text { response }\end{array}$ & $\begin{array}{c}\text { Correct } \\
\text { response }\end{array}$ & P-value & $\begin{array}{c}\text { I do not } \\
\text { know }\end{array}$ \\
\hline Q6 & 14 & 3 & 0.1696 & 16 \\
Q7 & 4 & 26 & $0.0029^{*}$ & 3 \\
Q8 & 14 & 19 & $0.0001^{*}$ & \\
Q9 & 13 & 16 & $0.0031^{*}$ & 4 \\
\hline
\end{tabular}

* significant difference (Chi-square, $\mathrm{P}<0.05$ ) participants provided the correct answer that replantation should be done within 30 minutes after the tooth avulsion occurred. Correct responses to all knowledge based questions were provided by two participants $(6.1 \%)$ while only one participant $(3.0 \%)$ admitted she did not know the answer and chose the answer "I do not know" when it was offered.

\section{Discussion}

Kindergarten teachers in Croatia provide pre-school education to children until they enter school at the age of six, or less often at the age of seven. Their knowledge on distinguishing deciduous from permanent teeth is very important if an accident of tooth avulsion happens. Current study showed that neither of participants received any kind of information on the management of a knocked-out tooth, indicating that they were not educated to distinguish the difference between a primary and a permanent tooth nor what should be done in case of an emergent dental event of primary tooth avulsion. This finding emphasizes the need for better official communication between dentists and kindergarten professionals. A study in Singapore indicates that nearly all participants of pre-school teachers were enthusiastic about public education implemented to improve their knowledge on dental trauma ${ }^{12}$.

About 27.3\% of participants experienced tooth injuries among kindergarten children. The majority of participants confirmed to understand terms of a knocked-out tooth and a tooth replantation and were aware that the knocked-out tooth should be placed back into socket. This finding is similar to the results of another study in urban area among school teachers ${ }^{9}$. In previous research on dental injuries, tooth avulsions were present from $4 \%$ to $22 \%$ depending on the study ${ }^{13}$ and they were more often observed among deciduous dentition traumatic injuries ${ }^{2-3}$. According to that finding, every kindergarten teacher

TABLE 3

RESPONSE FREQUENCY OF KINDERGARTEN TEACHERS REGARDING APPROPRIATE CLEANING (Q7) AND TRANSPORT (Q9) MEDIUM FOR AVULSED TOOTH

\begin{tabular}{|c|c|c|c|c|c|c|}
\hline $\mathrm{Q} 9 \backslash \mathrm{Q} 7$ & $\begin{array}{c}\text { Brush crown } \\
\text { and root }\end{array}$ & $\begin{array}{l}\text { Wash with tap } \\
\text { water * }\end{array}$ & $\begin{array}{l}\text { Wash with } \\
\text { milk* }\end{array}$ & $\begin{array}{l}\text { Wash with } \\
\text { saline * }\end{array}$ & Do not wash & I do not know \\
\hline Tissue paper & & 3 & & & 2 & 2 \\
\hline \multicolumn{7}{|l|}{ Toilet paper } \\
\hline Cotton rolls & & & & 2 & & \\
\hline \multicolumn{7}{|l|}{ Pocket } \\
\hline Poly bags & & & & 2 & & \\
\hline Tap water & & 1 & 1 & & & \\
\hline Saline water* & & & & $10 *$ & 1 & \\
\hline Milk * & & $1^{*}$ & $4^{*}$ & & & \\
\hline \multicolumn{7}{|l|}{ Saliva * } \\
\hline \multicolumn{7}{|l|}{ Others } \\
\hline I do not know & & 1 & & 1 & 1 & 1 \\
\hline
\end{tabular}

\footnotetext{
* correct answer
} 
should be aware that the avulsed primary tooth should not be replanted ${ }^{4}$. In the critical review of arguments regarding the topic of primary tooth replantation ten situations should be avoided and it is suggested that it should be performed only in ideal conditions by a dental professional. Due to the proximity of the developing permanent tooth bud to the socket of the primary incisor, special attention should be paid when manipulating instruments into the socket ${ }^{14}$. When parents choose the replantation of an avulsed primary tooth, they should save it in the container with medium for tooth transport according to the guidelines for transport of avulsed permanent tooth provided by the IADT ${ }^{14-15}$. Parents should also be aware that after the replantation frequent clinical and radiographic evaluations are very important to detect any sign of possible sequelae on the permanent successor at an early stage when the sequelae start to develop ${ }^{15}$.

The majority of participants would go to the nearest dentist to seek the replantation treatment. However, $42.4 \%$ of participants answered incorrectly similar to the study among school teachers ${ }^{11}$. This finding indicates the need to increase awareness that this emergency event should be treated either at the nearest dental surgery or at a general hospital with employed dentist.

Only $9.1 \%$ of participants were aware that replantation should be performed within 30 minutes since tooth avulsion. None of participants responded that the replantation should be performed within 5 minutes indicating that an immediate replantation performed by them or some other non-professional person at the site of accident was not under their consideration. According to literature data nonprofessionals are too scared to replant the tooth immediately at the site of accident. Most participants respond that lack of knowledge and training prevents them to choose this approach to the emergent event of the avulsed tooth. Some legal implications are also among the reasons that prevent immediate replantation at the site of accident by a non-professional person ${ }^{5-7}$. It has been found that participants are afraid to be sued for replanting the avulsed tooth incorrectly ${ }^{7}$. A clarification is required regarding issues of responsibility and acceptable levels of competence for professionals other than dentists, who may be expected to provide emergency care during the critical moments following traumatic dental injuries such as avulsion ${ }^{5}$. According to the guidelines of IADT, the avulsed permanent tooth should be replanted by encouraging the immediate replantation at the site of accident ${ }^{4}$, but non-professionals rather choose not to perform it. As kindergarten teachers could encounter either the primary or permanent tooth avulsion they should be encouraged to use the container with a medium for the transport of the avulsed tooth instead of replanting it by themselves.

Regarding the cleaning medium, $78.8 \%$ of participants chose one of the correct answers which is a better finding than those found by similar studies among different groups of non-professionals ${ }^{9-11}$. If the tooth falls on the ground and gets dirty, it should be picked up by the crown and washed briefly, not longer than 10 seconds, by an appropriate medium 4 . It is a good finding that none of the participants chose to brush the crown and the root since additional mechanical damage to the root cells should be avoided. The best choice of the cleaning medium would be the same medium as the one to be used for transport.

Only $30.3 \%$ of participants would use saline water for both cleaning and transport of the avulsed tooth providing appropriate pre-hospital conditions for the successful replantation of the avulsed tooth. However, physiological saline in specialized transport containers, as well as culture media, are presently consider to be impractical as they are not generally available at the accident sites where injury is likely to occur ${ }^{16-17}$.

Appropriate physiological storage media available near the site of the accident are milk and patient saliva ${ }^{16}$. In the current study, $12.1 \%$ of participants would use milk as both cleaning and transport medium while none would use saliva as storage medium. As to the usage of milk as cleaning and transport medium it has been found that refrigerated milk is preferable to milk at room temperature $^{16,18}$, as well as reduced fat milk instead of whole milk ${ }^{19-20}$ while long shelf-life milk can be recommended as a suitable transport medium for the avulsed teeth ${ }^{21}$. It has also been found that milk is better transport medium than patient saliva since microorganisms from saliva may affect the survival of the periodontal ligament cells ${ }^{22-23}$.

The tap water was chosen by $18.2 \%$ of participants for cleaning and by $6.1 \%$ for transport medium. Transport of the avulsed tooth is not appropriate using a container with tap water since a decrease of vitality of the periodontal ligament cells and an increase of external root resorption are associated with the extended storage in water ${ }^{18}$. The IADT guidelines recommend brief wash under cold running water before encouraging the patient/guardian to replant the tooth back in place and bite on handkerchief to hold it in position ${ }^{4}$.

Some type of dry transport would be used by $33.3 \%$ of participants, which is similar to the response of school teachers from rural area ${ }^{9}$. In the current study, most of participants would use tissue paper while fewer would use either cotton rolls or poly bags. Any type of a dry transport is appropriate since the period of dryness is related to successful tooth replantation. It is very important that drying of the avulsed tooth do not pass over the critical limit of 15-minute period ${ }^{17}$. It has been found that a dry storage time of 5 minutes or less has limited potential for an early onset of resorption, but that a marked effect is seen after 15 minutes $^{24}$. Also it was reported that additional 10 minutes of dryness would increase the probability of resorption by $29 \%{ }^{25}$. This indicates that within 5 minutes the avulsed tooth should be either immediately replanted or stored in a wet medium for tooth transport.

The immediate response to the permanent tooth avulsion is very important since an appropriate response provided by a non-professional person will increase chances for a successful tooth replantation. As many as $57.6 \%$ of participants knew what should be done if the tooth was knocked-out and fell on the ground. That is a better result than those obtained by similar studies among non-profes- 
sionals $^{9-10}$. However, the current study showed a lack of knowledge of kindergarten teachers regarding pre-hospital response to an emergent event of the tooth avulsion, since only $6.1 \%$ of participants would choose its management which would include the usage of appropriate both a cleaning and a transport medium and would seek for help by the nearest dentist within 30 minutes. Only $3.0 \%$ of participants were aware that they did not know which response was correct and chose the corresponding answer when offered. This indicates that the majority of $90.9 \%$ participants were not aware that they would provide an inappropriate response to the avulsed tooth.

\section{Conclusions}

The fact that kindergarten teachers mostly educate children without permanent teeth does not justify their low level of knowledge regarding the pre-hospital emergency management of tooth avulsion. Since they work with children, parents should expect them to know how to react appropriately if they witness an accident with the tooth avulsion and/or to provide an advice for them prior to visiting the nearest dentist. Every kindergarten teacher should be well informed what should be done if some type of dental injury happens and how to distinguish primary from permanent teeth. Due to the possible damage of dental follicles of permanent teeth, primary teeth are not replanted.

The IADT guidelines of the pre-hospital emergency management of tooth avulsion should become an obligatory part of education for kindergarten teachers. The kindergarten educators should be encouraged to use a container with transport medium rather than to perform replantation of the permanent tooth after a traumatic avulsion. Every childcare worker should be well informed where is the nearest dentist during working hours as well as the address where to seek help after the working hours. Periodically, educational campaigns dedicated to this topic are recommended, leaflets should be shared among kindergarten teachers and their knowledge eavaluated. The official communication between dental professionals and kindergarten teachers should be improved at both local and regional level.

\section{R E F E R E N C E S}

1. ANDREASEN JO, Scand J Dent Res, 78 (1970) 329. DOI:10.1111/j.1600-0722.1970.tb02080.x. - 2. CHOI SC, PARK JH, PAE A, KIM JR, Dent Traumatol, 26 (2010) 70. DOI:10.1111/j.16009657.2009.00840.x. - 3. MARKOVIC D, VUKOVIC A, VUKOVIC R, SOLDATOVIC I, Vojnosanit Pregl, 71 (2014) 845. DOI: 10.2298/VSP130420042. - 4. ANDERSSON L, ANDREASEN JO, DAY P, HEITHERSAY G, TROPE M, DIANGELIS AJ, KENNY DJ, SIGURDSSON A, BOURGUIGNON C, FLORES MT, Dent Traumatol, 28 (2012) 88. DOI:10.1111/j.1600-9657.2012.01125.x. - 5. ADDO ME, PAREKH S, MOLES DR, ROBERTS GJ, Br Dent J, 202 (2007) E27. DOI:10.1038/ bdj.2007.328. - 6. BLAKYTNY C, SURBUTS C, THOMAS A, HUNTER ML,IntJ Paediatr Dent, 11(2001)327.DOI:10.1046/j.0960-7439.2001.00288.x. - 7. HAMILTON FA, HILL FJ, MACKIE IC, Endod Dent Traumatol, 13 (1997) 19. DOI:10.1111/j.1600-9657.1997.tb00004.x. — 8. IVANCIC JOKIC N, BAKARCIC D, GRZIC R, MAJSTOROVIC M, SOSTAREK M, Eur J Dent Educ, 21 (2017) e131. DOI:10.1111/eje.12235. — 9. KAUR M, GUPTA K, GOYAL R, CHAUDHARY N, Int J Sci Study, 1 (2014) 17. — 10. PANZARINI SR, PEDRINI D, BRANDINI DA, POI WR, SANTOS MF, CORREA JPT, SILVA FF, Dent Traumatol, 21 (2005) 324. DOI:10.1111/j. 16009657.2005.00327.x. - 11. PRASANNA S, GIRIRAJU A, NARAYAN NL, Int J Clin Pediatr Dent, 4 (2011) 203. DOI:10.5005/jp-journals-10005-1110. - 12. SAE-LIM V, LIM LP, Dent Traumatol, 17 (2001) 71. DOI:10.1034/j.1600-9657.2001.017002071.x. — 13. BASTONE EB, FREER
TJ,MCNAMARAJR, Aust Dent J, 45 (2000) 2. DOI:10.1111/j.1834-7819.2000. tb00234.x. - 14. HOLAN G, Dent Traumatol, 29 (2013) 178. DOI:10.1111/ edt.12038. - 15. MARTINS-JUNIOR PA, FRANCO FA, DE BARCELOS RV, MARQUES LS, RAMOS-JORGE ML, Int J Paediatr Dent, 24 (2014) 77. DOI:10.1111/ipd.12075. — 16. BARRETT EJ, KENNY DJ, Endod Dent Traumatol, 13 (1997) 153. DOI:10.1111/j.1600-9657.1997.tb00031.x. — 17. TROPE M, Dent Traumatol, 18 (2002) 1. DOI:10.1046/j. 1600 4469.2001.00001.x. - 18. LEKIC P, KENNY D, MOE HK, BARRETTI E, MCCULLOCH CA, J Periodontal Res , 31 (1996) 294. DOI:10.1111/ j.1600 0765.1996.tb00496.x. - 19. HARKACZ OM, CARNES DL, WALKER WA, J Endod, 23 (1997) 687. DOI:10.1016/S0099-2399(97)80402-5. - 20. SIGALAS E, REGAN JD, KRAMER PR, WITHERSPOON DE, OPPERMAN LA, Dent Traumatol, 20 (2004) 21. DOI:10.1111/j.1600-4469.2004.00219.x. — 21. MARINO TG, WEST LA, LIEWEHR FR, MAILHOT JM, BUXTON TB, RUNNER RR, MCPHERSON JC, J Endod, 26 (2000) 699. DOI:10.1097/00004770-200012000-00005. - 22. POI WR, SONODA CK, MARTINS CM, MELO ME, PELLIZZER EP, DE MENDONCA MR, PAN ZARINI SR, Braz Dent J, 24 (2013) 437. DOI: 10.1590/0103-6440201302297. - 23. LINDSKOG S, BLOLOF L, Acta Odontol Scand, 40 (1982) 435. DOI:10.3109/ 00016358209025118. - 24. DONALDSON M, KINIRONS MJ, Dent Traumatol, 17 (2001) 205. DOI:10.1034/j.1600-9657.2001.170503.x. — 25. KINIRONS MJ, GREGG TA, WELBURY RR, COLE BO, Br Dent J, 189 (2000) 263. DOI:10.1038/sj.bdj.4800740.

\section{Matijević}

Faculty of Dental Medicine and Health, University of Osijek, Cara Hadrijana 10E, 31000 Osijek, Croatia e-mail: marko.matijevic@fdmz.hr 
ZNANJA I STAVOVI ODGOJITELJA U HRVATSKIM DJEČJIM VRTIĆIMA O HITNOM ZBRINJAVANJU AVULZIJE ZUBA

\section{S A Ž E T A K}

Cilj ovog istraživanja bio je procijeniti znanje hrvatskih odgojitelja o zbrinjavanju avulzije zuba prije ambulantnog liječenja. Presječno istraživanje provedeno je sa 33 odgojitelja u dječjim vrtićima (prosječne starosti 43,9 \pm 9,7 godina). Upitnik je sadržavao 10 pitanja s dva do jedanaest mogućih odgovora. Statistička značajnost utvrđena je hi-kvadrat testom. Većina ispitanika nije imala iskustva s ozljedom zuba kod djece vrtićke dobi. Na pitanja o poznavanju pojmova izbijenog zuba, reimplantacije zuba i da li je potrebno izbijeni zub reimplantirati potvrdno je odgovorilo $90,9 \%, 57,6 \%$ odnosno $63,6 \%$ ispitanika. Samo je 9,1\% ispitanika točno odgovorilo da bi reimplantaciju zuba trebalo obaviti u periodu od 30 minuta. Ukupno 78,8\% ispitanika izabralo bi ispravan medij za čišćenje ako je izbijeni zub onečišćen. Zub bi u odgovarajućem mediju transportiralo $48,5 \%$ ispitanika. Točne odgovore o vrsti transportnog medija i čišćenju izbijenog zuba dalo je $45,5 \%$ ispitanika. Ukupno $57,6 \%$ ispitanika zatražilo bi pomoć za reimplantaciju zuba kod najbližeg doktora dentalne medicine. Nijedan ispitanik nikada nije dobio nikakvu informaciju o liječenju izbijenog zuba. Odgojitelji u dječjem vrtiću nemaju dovoljno znanja za hitno zbrinjavanje prilikom avulzije zuba. Svi odgojitelji u dječjim vrtićima trebali bi biti dobro informirani o tome kako postupiti prilikom ozljede zuba. Komunikaciju između doktora dentalne medicine i odgojitelja u dječjim vrtićima potrebno je poboljšati na lokalnoj i regionalnoj razini. 